\title{
Micropropagation of the Pineapple Lily, Dasypogon hooked J. Drumm.
}

\author{
Eric Bunn and Kingsley W. Dixon \\ Kings Park and Botanic Garden, West Perth, Western Australia 6005 \\ Australia
}

Additional index words. arborescent monocot, tissue culture, in vivo rooting, ornamental

Three genera of arborescent monocots (Staff and Waterhouse, 1981) are native to Western Australia. The genus Dasypogon (Dasypogonaceae) is endemic to Western Australia and contains three species. Dasypogon hookeri, or pineapple lily, is common in the extreme southwest of Western Australia and is the only arborescent member of the genus, attaining heights of up to $4 \mathrm{~m}$. Dasypogon hookeri produces numerous straplike leaves 30 to $40 \mathrm{~cm}$ long and heads of white drumstick flowers in the spring. The height and flowers of $D$. hookeri make it an attractive garden plant (Fig. 1a).

The terminal shoot of $D$. hookeri has not been observed to branch; however, basal clusters of shoots, some produced at the end of 20 - to $30-\mathrm{cm}-$ long underground rhizomes, occur after burning of the habitat. Removal or damage to the apical meristem is likely to result in the death of the plant. To date no method other than transplanting whole plants has been successful for propagating this species. This paper details in vitro methods of propagation and establishment in pots of $D$. hookeri using basal shoot clusters as explant sources.

Shoots were excised from clumps of shoots arising from the stem base of a 1-m-tall plant in its natural habitat that had been subjected to a moderate-intensity bush fire 8 months earlier. The tough outer leaves were removed and the shoots washed under running tap water for $\approx 1 \mathrm{~h}$ and surface sterilized for $7 \mathrm{~min}$ with agitation in $1 \% \mathrm{w} / \mathrm{v}$ sodium hypochlorite with $0.05 \% \mathrm{w} / \mathrm{v}$ Tween- 80 . Shoots were rinsed in three changes of sterile distilled water, and the outer leaves were carefully removed, taking care not to damage the sheathing leaf base enclosing the apical meristem. These tissues containing the apical meristem were then rinsed for $5 \mathrm{sec}$ in $0.5 \%$ sodium hypochlorite only, rinsed thoroughly in sterile distilled water, and dried on sterile filter paper. Twenty-two shoots were placed in 30-ml-capacity polycarbonate tubes (with closures) containing $10 \mathrm{ml}$ of Murashige and Skoog (1962) major and minor mineral salts, supplemented with $100 \mu \mathrm{M}$ sodium-ferric EDTA, $500 \mu \mathrm{M}$ myo-inositol, $3 \mu \mathrm{M}$ thia-

Received for publication 27 June 1990. Accepted for publication 27 Sept. 1991. The cost of publishing this paper was defrayed in part by the payment of page charges. Under postal regulations, this paper therefore must be hereby marked $a d$ vertisement solely to indicate this fact. mine $\mathrm{HCl}, 2.5 \mu \mathrm{M}$ pyridoxine $\mathrm{HCl}, 4 \mu \mathrm{M}$ nicotinic acid, $90 \mathrm{~mm}$ sucrose, $\mathrm{pH}$ 6.0, and $0.1 \% \mathrm{w} / \mathrm{v}$ agar. Media were autoclaved at $121 \mathrm{C}$ for $15 \mathrm{~min}$ and sloped to cool. Cultures were placed under cool-white fluorescent lamps with light intensity of $40 \mu \mathrm{mol} \cdot \mathrm{m}^{-2} \cdot \mathrm{s}^{-1}$ at culture level and 16/8 h light/dark. About $60 \%$ of primary explants were contaminated with bacteria after 14 to 21 days. A further $10 \%$ attrition of shoots occurred as a result of vitrification that became evident 2 to 3 weeks after culture.

Four weeks after initiation, sterile shoots were transferred to MS medium containing $\mathrm{N}$ - (phenylmethyl)-1 $\mathrm{H}$ - purine-6-amine (BA) at 1 and $10 \mu \mathrm{M}$ and incubated for 5 weeks. Shoot multiplication was assessed after the fifth and sixth passages on multiplication medium. Each treatment was repeated twice with a total of 25 shoots per treatment, and results were pooled. A 3- to 5-fold increase (mean number of shoots per explant, $3.8 \pm$ 0.3) per 20-mm-long explant was achieved with $1 \mu \mathrm{M}$ A (Fig. 1b. A > 12-fold shoot increase (mean number of shoots per explant, $12.2 \pm 0.6)$ was achievable with $10 \mu \mathrm{M} \mathrm{BA}$. Shoots were stunted on medium with BA at

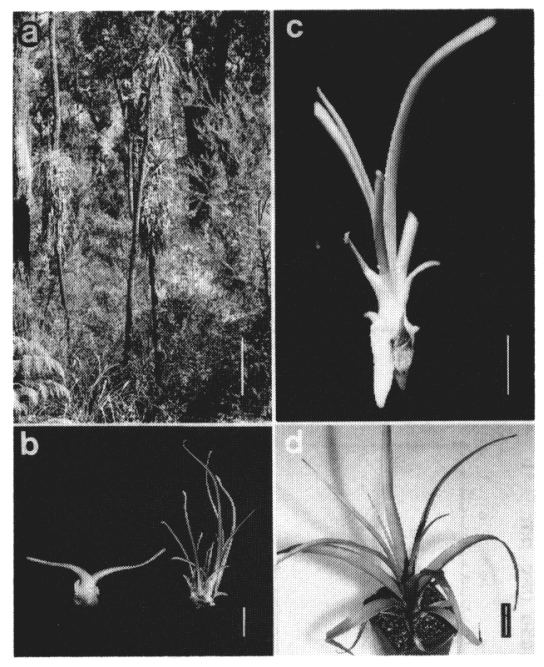

Fig. 1. Plants and shoots of Dasypogon hookeri: (a) growing in Jarrah (Eucalyptus marginata Donn ex Smith) woodland south of Perth, Western Australia; bar = $25 \mathrm{~cm}$; (b) with basal shoot clusters (left) and elongated basal shoots (right) ready for division for continued culture or potting out as microcuttings, bar $=1 \mathrm{~cm}$; (c) showing root development on a microcutting after 6 weeks, bar $=1 \mathrm{~cm}$; (d) 6 months after removal from culture to potting $\mathrm{mix}, \mathrm{bar}=3 \mathrm{~cm}$.
$10 \mu \mathrm{M}$ and required an intermediate period of elongation on MS without growth hormones. Elongation of shoots on medium with $1 \mu \mathrm{M}$ BA was not required. Also, the incidence of vitrification was more frequent at $10 \mu \mathrm{M}$ BA. Previous trials on a related species, Calectasia grandiflora Preiss (Xanthorrhoeaceae), indicated that BA was most effective in inducing shoot proliferation compared with other cytokinins (E.B., unpublished).

Root induction was tested in vitro by incubating unrooted shoots on half-strength MS medium supplemented with either $1 \mathrm{H}$ - indole-3-butyric acid (IBA) or $\alpha$ - naphthaleneacetic acid (NAA) at 1,5 , and $10 \mu \mathrm{M}$, but was not successful. We also used nonrooted shoots in vitro that were acclimatized in a shaded area of a greenhouse for 1 week. These shoots were removed from the culture vessels and their bases dusted with softwood rooting powder containing IBA at $0.1 \% \mathrm{w} /$ w. Incubation time was 5 weeks and a total of 50 shoots were used in two trials. The shoots were then potted into $100-\mathrm{ml}$ black plastic pots containing equal volumes of peat that was pasteurized at $70 \mathrm{C}$ for $1 \mathrm{~h}$ and unpasteurized perlite. Potted plants were maintained in a constantly fogged glasshouse for 3 weeks, then moved to intermittent misting until rooting was observed. The mean percentage of shoots forming roots after 2 months was $69.8 \% \pm 8.5 \%$. Dasypogon hookeri produces fleshy leaves that appear able to resist desiccation, and shoots are able to remain turgid until roots form. Roots were initially short and thick, i.e., 5 to $10 \mathrm{~mm}$ long and 2 to $3 \mathrm{~mm}$ in diameter, followed by production of finer lateral roots (Fig. 1c). After 6 months some plants developed additional basal shoots. All plants responded to repotting into $250-\mathrm{ml}$ pots containing a noncommercial potting mixture of equal volume of composted wood fines : coarse sand : perlite, supplemented with inorganic fertilizer and pasteurized at $70 \mathrm{C}$ for $1 \mathrm{~h}$. After 2 to 3 months, plants were transferred to routine nursery conditions. At 1 year, plants had grown vigorously (Fig. 1d), producing leaves up to $30 \mathrm{~cm}$ long.

This study outlines a basic in vitro propagation procedure using direct in vivo rooting for D. hookeri. Additional development of the techniques described (e.g., trying other cutting powders, liquid or gel auxin dips to improve rooting) would expedite commercial propagation of this attractive species.

\section{Literature Cited}

Murashige, T. and F. Skoog. 1962. A medium for rapid growth and bio-assays with tobacco tissue cultures. Physiol. Plant. 15:473-497.

Staff, I.A. and J.T. Waterhouse. 1981. The biology of arborescent monocotyledons with special reference to Australian species. p. 216-2.57. In: J.S. Pate and A.J. McComb (eds.). The biology of Australian plants. Univ. of Western Australia Press, Nedlands, Western Australia. 